\title{
Hyponatremia due to duloxetine use in an elderly woman patient
}

\section{Yaşlı bir kadın hastada duloksetin kullanımına bağı hiponatremi}

\author{
Buket Cinemre ${ }^{1}$ (D), Ali Erdogan ${ }^{* *}$ (D), Burak Kulaksizoglu ${ }^{1}$ (D), Sinan Mert Bingol ${ }^{1}$ (iD \\ ${ }^{1}$ Department of Psychiatry, Akdeniz University Medical Faculty, 07070 Antalya, Turkey \\ * Corresponding author: Ali Erdogan E-mail: erdoganali006@hotmail.com ORCID: 0000-0003-0329-6778 \\ Received: 22 April 2020 Accepted: 28 June 2020
}

\begin{abstract}
Hyponatremia is a potentially dangerous side effect of antidepressants. Almost every antidepressant can cause hyponatremia. Duloxetine-induced hyponatremia is a side effect that is usually seen in older women. In addition to advanced age and female sex; low body weight, presence of comorbid diseases are other important risk factors for the development of hyponatremia. In this case report we present a patient with depressive disorder who developed hyponatremia with duloxetine treatment which resolved immediately after the cessation of the medication with supportive electrolyte treatment. In our case, the resolution of hyponatremia with supportive electrolyte treatment in addition to the cessation of duloxetine reminds us about the importance of monitoring sodium levels both before and after antidepressant treatment in geriatric populations.
\end{abstract}

Keywords: hyponatremia, duloxetine, antidepressant side effect

\section{öz}

Hiponatremi, antidepresanların potansiyel olarak tehlikeli bir yan etkisidir. Hemen hemen her antidepresan hiponatremiye neden olabilir. Duloksetin kaynaklı hiponatremi genellikle yaşıı kadınlarda görülen bir yan etkidir. Ileri yaş ve kadın cinsiyetine ek olarak; düşük vücut ağırlığı, komorbid hastalıkların varlığı hiponatremi gelişimi için diğer önemli risk faktörleridir. Bu olgu sunumunda, ilacın kesilmesinden hemen sonra düzelen duloksetin tedavisi ile hiponatremi gelişen depresif bozukluğu olan bir hasta sunulmaktadır. Bizim olgumuzda, duloksetin kesilmesine ek olarak, hiponatreminin destekleyici elektrolit tedavisi ile çözülmesi bize geriatrik popülasyonlarda antidepresan tedavisinden önce ve sonra sodyum seviyelerinin izlenmesinin önemini hatırlatmaktadır.

Anahtar kelimeler: hiponatremi, duloksetin, antidepresan yan etkisi 


\section{INTRODUCTION}

Duloxetine is an antidepressant included in the pharmacological class of serotonin-norepinephrine reuptake inhibitors (SNRIs). The drug is approved for the treatment of major depressive disorder, generalized anxiety disorder, diabetic peripheral neuropathic pain, fibromyalgia, chronic musculoskeletal pain and stress urinary incontinence. The drug is generally safe and well tolerated across all approved indications in adults at doses ranging from 60 to $120 \mathrm{mg} /$ day. The most commonly reported adverse reactions were nausea, dry mouth, somnolence, constipation, decreased appetite and hyperhidrosis, which occurred mainly in the early stages of the assumption and disappeared after the first weeks of treatment [1].

Hyponatremia is the most common electrolyte imbalance disorder in hospitalized patients, defined as a serum sodium level below $135 \mathrm{mEq} / \mathrm{L}$ which is associated with increased mortality, morbidity, and prolonged hospitalization [2]. Normovolemic hyponatremia accounts for approximately $60 \%$ of chronic hyponatremia where the most common reason is inappropriate anti-diuretic hormone (ADH) secretion. Inappropriate ADH secretion is known to be responsible for medication as well as medical conditions such as cancer, infection, head trauma. Selective serotonin reuptake inhibitors (SSRIs) and other antidepressant drugs are known to induce inappropriate ADH secretion [3].

In this case study, we presented a patient who developed severe hyponatremia due to the use of duloxetine and we aimed to discuss drug-induced hyponatremia.

\section{CASE PRESENTATION}

Our case was an 80-year-old female patient. She had anhedonia, depressive mood and loss of appetite, waxing and waning in severity for the last 30 years. Thus, from time to time she was put on a variety of antidepressant treatment including venlafaxine, escitalopram, mirtazapine and fluoxetine. Over the last couple of years these complaints worsened with the addition of anxiety symptoms.

The patient, whose depressive complaints had increased for the last one month, was hospitalized with the diagnosis of mixed anxiety-depression. Her routine blood tests revealed only a mild creatinine elevation. After her admission to the clinic, she was put on a combination of duloxetine 30 $\mathrm{mg} /$ day, sulpiride $50 \mathrm{mg} /$ day and hyosin $\mathrm{N}$-methylbromidemedazepam $10 \mathrm{mg} /$ day treatment. Duloxetine was then increased to $60 \mathrm{mg}$ daily and because she had a history of hypertension she continued to take her antihypertensive treatment which was $50 \mathrm{mg}$ of metoprolol and $10 \mathrm{mg}$ of lercadipine per day. Since an increase in her hepatic enzymes [Alanine aminotransferase (ALT): $91 \mathrm{U} / \mathrm{L}$; Reference value: 0-34 U/L, Aspartate aminotransferase (AST): $71 \mathrm{U} / \mathrm{L}$; Reference value: $0-31 \mathrm{U} / \mathrm{L}$ ] were observed in the next blood test, duloxetine was reduced to $30 \mathrm{mg}$ for a couple of days. However; sulpiride and hyosin N-methylbromidemedazepam which can elevate hepatic enzymes were discontinued. ALT and AST values returned to normal 3 days after treatment change. About a week later, she had to be consulted to the cardiology doctor because of a sudden edema in her legs. The patient described a mild polydipsia and there was no polyuria. The cardiologist, after a series examination and diagnostic tests concluded that she had a mild aortic insufficiency and a severe tricuspid regurgitation for which an aldactazide treatment was initiated. In the meantime, severe hyponatremia [Serum sodium $\left(\mathrm{Na}^{+}\right)$: 114.1 $\mathrm{mEq} / \mathrm{L}$; Reference value: 135-145 mEq/L] was added. In addition, the patient's serum potassium $\left(\mathrm{K}^{+}\right)$value was 4.94 $\mathrm{mEq} / \mathrm{L}$ [Reference value: $3.5-5.3 \mathrm{mEq} / \mathrm{L}$ ] and creatinine was $1.25 \mathrm{mg} / \mathrm{dL}$ [Reference value: 0.6-1.2 mg/dL]. Nephrology consultation was requested and the nephrologist suggested that hyponatremia might be related to duloxetine treatment. Treatment of duloxetine was stopped and electroconvulsive therapy (ECT) was started. In the preparation phase for the ECT, small pulmonary nodule in the subpleural space and atelectasis were detected in her lungs. Since her electrolyte balance deteriorated the drug treatment was stopped and an ECT treatment was planned. The $\mathrm{Na}^{+}$value of the patient returned to normal limits $\left(\mathrm{Na}^{+}\right.$: $134.4 \mathrm{mEq} / \mathrm{L}) 10$ days after discontinuation of duloxetine with supportive electrolyte treatment. On the first day, 150 $\mathrm{ml}$ of $3 \%$ hypertonic saline intravenous infusion was administered twice in 5 hours. Then $0.9 \%$ isotonic was applied for 4 days. After duloxetine has also been stopped, the patient started to take ECT treatment, which was administered three times per week. The patient was in full recovery when a total of 8 sessions was completed.

\section{DISCUSSION}

In this case report, we presented a case of hyponatremia after duloxetine treatment in an elderly female patient who also had renal parenchymal disease.

Inappropriate $\mathrm{ADH}$ secretion due to hypothyroidism, diuretic use, renal pathology, lung pathology, brain lesions, and drugs -in this case duloxetine, were possible explanations for the hyponatremia observed in this patient. Since there was no clinical or laboratory evidence, a thyroid dysfunction was easily excluded. Likewise, any central nervous system lesion or pathology was also excluded for the same reason. 
The patient was on a diuretic treatment which could readily be the reason for the development of hyponatremia. However, this hyponatremia improved after some time despite the fact that the patient continued to take her diuretic medication until the end of her stay. This suggests that the antidiuretic drug used by the patient is unlikely to be responsible for hyponatremia.

The patient's lung pathology (nodular lesion) and renal pathologies (chronic parenchymal disease) may both cause hyponatremia. However, these are most likely to be chronic conditions which may be expected to lead to hyponatremia long before this occasion. Furthermore, the recovery of hyponatremia soon after its occurrence suggests that it is possibly not related to these chronic conditions but to some temporary etiology like the use of a drug, in this case duloxetine. Indeed, hyponatremia occurred shortly after the initiation of duloxetine in this patient and it gradually aggravated as long as the patient continued to take this drug. Finally, it rapidly recovered after the discontinuation of the drug, which seems to strengthen this temporal relationship.

Almost all antidepressant drugs may cause hyponatremia [4]. Fluoxetine-associated hyponatremia is reported to be the most prevalent among SSRIs. Research findings suggest that, there is not a correlation between the dose of SSRIs and the onset or severity of hyponatremia [5]. However, it is noteworthy that female gender and advanced age are important risk factors for the development of hyponatremia with antidepressant treatment [6].

For the development of hyponatremia with duloxetine; advanced age and female gender, low body weight, history of hyponatremia, presence of comorbid diseases are reported as important risk factors [7]. In our case, all other risk factors were observed except for a low body weight and a history of hyponatremia. Particularly, chronic kidney disease and concomitant diuretic use might have facilitated the development of hyponatremia with the initiation of duloxetine even though they have not led to a serious electrolyte imbalance on their own until then.

Cases of hyponatremia induced by duloxetine have been described in the literature $[8,9]$. Our patient's presentation is consistent with literature reports of elderly females who developed hyponatremia within days of being initiated on duloxetine [10-12].

The main treatment for antidepressant induced hyponatremia is the cessation of antidepressant medication and supportive treatment [3]. In our case, in addition to the cessation of duloxetine treatment, hyponatremia was managed with adequate fluid-electrolyte treatment and close monitoring of serum electrolytes and renal functions.

This case report underlines the importance of monitoring serum sodium levels before and after antidepressant drug treatment, because the risk of drug-induced hyponatremia can increase in the geriatric population with chronic diseases which commonly end up with multiple pharmacological treatment.

\section{CONCLUSION}

Serum $\mathrm{Na}^{+}$concentrations should be monitored in the early stages of the duloxetine treatment of patients, especially elderly patients. The use of duloxetine should be remembered in the differential diagnosis of drug-induced hyponatremia.

\section{DECLARATION OF CONFLICT OF INTEREST}

The authors received no financial support for the research and/or authorship of this article. There is no conflict of interest.

\section{REFERENCES}

1. Muscatello MRA, Zoccali RA, Pandolfo $G$, Mangano $P$, Lorusso S, Cedro $C$, et al. Duloxetine in Psychiatric Disorders: Expansions Beyond Major Depression and Generalized Anxiety Disorder. Front Psychiatry. 2019; 10: 772. (doi: 10.3389/fpsyt.2019.00772).

2. Hoorn, EJ, Lindemans J, Zietse R. Development of severe hyponatraemia in hospitalized patients: treatmentrelated risk factors and inadequate management. Nephrol Dial Transplant. 2006; 21(1): 70-6. (doi: 10.1093/ndt/gfi082).

3. Peri A, Giuliani C. Management of euvolemic hyponatremia attributed to SIADH in the hospital setting. Minerva Endocrinol. 2014; 39(1):33-41.

4. De Picker L, Van Den Eede F, Dumont G, Moorkens G, Sabbe BG. Antidepressants and the risk of hyponatremia: a class-by-class review of literature. Psychosomatics 2014; 55(6): 536-47. (doi: 10.1016/j.psym.2014.01.010).

5. Liu BA, Mittmann N, Knowles SR, Shear NH. Hyponatremia and the syndrome of inappropriate secretion of antidiuretic hormone associated with the use of selective serotonin reuptake inhibitors: a review of spontaneous reports. [published correction appears in Can Med Assoc J 1996 Oct 15; 155(8): 1043]. CMAJ. 1996; 155(5): 519-27. 
6. Viramontes TS, Truong H, Linnebur SA. AntidepressantInduced Hyponatremia in Older Adults. Consult Pharm. 2016; 31(3): 139-50. (doi: 10.4140/TCP.n.2016.139).

7. Safdieh JE, Rudominer R. A case of hyponatremia induced by duloxetine. J Clin Psychopharmacol. 2006; 26(6): 675-6. (doi: 10.1097/01.jcp.0000246207.73034.96).

8. Sun CF, Chen YL, Li YH, Kumaraswamy M, Lo YC, Chen YT. Duloxetine-Induced Hyponatremia in an Elderly Male Patient with Treatment-Refractory Major Depressive Disorder. Case Rep Psychiatry. 2019; 2019: 4109150. (doi: 10.1155/2019/4109150).

9. Sahan E, Yıldız FBP. Duloxetine Induced Hyponatremia. Turk Psikiyatri Derg. 2019; 30(4). (doi: 10.5080/u23394).
10. Yoshida K, Aburakawa Y, Suzuki Y, Kuroda K, Kimura T. Acute Hyponatremia Resulting from Duloxetine-induced Syndrome of Inappropriate Antidiuretic Hormone Secretion. Intern Med. 2019; 58(13): 1939-42. (doi: 10.2169/internalmedicine.2346-18).

11. Takayama A, Nagamine T, Matsumoto Y, Nakamura M. Duloxetine and Angiotensin II Receptor Blocker Combination Potentially Induce Severe Hyponatremia in an Elderly Woman. Intern Med. 2019; 58(12): 1791-4. (doi: 10.2169/internalmedicine.2059-18).

12. Hu D, Wurster S. Hyponatremia Induced by Duloxetine: $A$ Case Report. Consult Pharm. 2018; 33(8): 446-9. (doi: 10.4140/TCP.n.2018.446). 